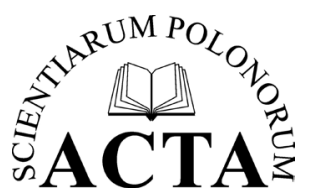

www.acta.urk.edu.pl/pl

Acta Sci. Pol.

Formatio Circumiectus 20 (1) 2021, 19-31

ENVIRONMENTAL PROCESSES

ISSN 1644-0765

DOI: http://dx.doi.org/10.15576/ASP.FC/2021.20.1.19

ORIGINAL PAPER

Accepted: 2.09.2020

\title{
SPATIAL-TEMPORAL CHARACTERIZATION OF METEOROLOGICAL DROUGHT USING THE STANDARDIZED PRECIPITATION INDEX. CASE STUDY IN ALGERIA
}

\author{
Meriem Fellag ${ }^{1}$, Mohammed Achite ${ }^{1}$ (D) 0000-0001-6084-5759, \\ Andrzej Wałęga ${ }^{2 \bowtie}$ (iD) 0000-0001-6839-4745 \\ ${ }^{1}$ Faculty of Nature and Life Sciences, Laboratory of Water \& Environment, University Hassiba Benbouali of Chlef, 02180 Chlef, \\ Algeria \\ 2 Department of Sanitary Engineering and Water Management, University of Agriculture in Cracow, Mickiewicza 24/28 Street, \\ 30-059 Cracow, Poland
}

\begin{abstract}
Aim of the study

In this study, the spatial and temporal characteristics of drought in the upper and middle Cheliff, a semi-arid region of northwestern Algeria, was examined using the standardized precipitation index [SPI] at an annual time scale, as a tool for measuring the severity of meteorological drought.
\end{abstract}

\section{Material and methods}

To assess the SPI, annual precipitation totals from 11 precipitation stations covering the period 1970-2009 were studied. In order to identify the possible changes in the precipitation trend of the studied series, appropriate statistical tests were selected. The extent, severity and duration of the drought in the studied area were obtained.

\begin{abstract}
Results and conclusions
Statistical tests revealed that the occurrence of ruptures in the rainfall regime was detected at the end of the 1970 s and at the beginning of 1980 s with a negative trend. The results of the SPI showed a strong prevalence of dry years after 1979 and 1980. The years 1993, 1999 and 2001 presented an extremely severe drought (SPI $<-2)$. The evolution of SPI showed a dominance of the frequency of normal years $(67 \%)$ and alternation of dry years $(17 \%)$ and wet years $(16 \%)$ over a period of 40 years. The total surface of the studied area had been affected by drought during severe years $(1993,1999)$. The study area exhibits irregularity and heterogeneity of drought due to the great variability of precipitation, which can vary from one sub-basin to another, and from one year to another.
\end{abstract}

Keywords: severity of drought, precipitation variability, standardized precipitation index, Algeria

\section{INTRODUCTION}

Drought is a recurring phenomenon and a complex natural hazard that affects every region of the world, every year. It is mainly related to rainfall deficit leading to a decrease in water supplies affecting the flora and fauna of a given region (Dracup et al., 1980; Wilhite and Glantz, 1985). The impact of drought on society, the environment, and the economy depends on its duration and spatial extent.

\footnotetext{
『e-mail: achitemohammed@gmail.com, andrzej.walega@urk.edu.pl
} 

tation Index. Case study... Acta Sci. Pol., Formatio Circumiectus, 20 (1), 19-31. DOI: http://dx.doi.org/10.15576/ASP.FC/2021.20.1.19

In Africa, drought is the most frequent climate catastrophe. Several studies have shown that drought depends on a significant reduction in annual rainfall (Paturel et al., 1997; Servat et al., 199), which has led to major humanitarian and economic crises in some countries such as Ethiopia (Edossa et al., 2010) and Somalia (Beltrando and Cambrelin, 1995).

Drought in Algeria is one of the most worrying manifestations of climate variability. Numerous droughts had already been observed at the beginning of the twentieth century, during the 1940s and since the 1970s (Seltzer, 1946; Demmak, 1982; Farmer and Wigley, 1985; Kadi, 1995).

North-west Algeria has also experienced many droughts of varying magnitude. The droughts of the 1940 s in western Algeria were due to a decrease in precipitation in the spring season, and in the 1980s, to a decrease in precipitation in the winter season (Matari and Douguedroit, 1995). The most recent droughts were even more remarkable for their spatial extent and intensity (Achite and Touaibia, 2007; Meddi and Hubert, 2003; Meddi and Meddi, 2009). They were typified by rainfall deficits (Hamlaoui-Moulai et al., 2013; Taibi et al., 2017; Zeroual et al., 2017) causing a notable decrease in monthly mean flows (Zeroual et al., 2013).

In order to characterize, evaluate and monitor drought, many indices have been proposed. Munger (1916), Blumenstock (1942) and McQuigg (1954) were among the first to suggest drought indices. Among the most widely used indexes are the Palmer Drought Severity Index (PDSI) (Palmer 1965), the Crop Moisture Index (CMI), the Surface Water Supply Index (SWSI), the Rainfall Anomaly Index (RAI), the standardized Precipitation Index (SPI), and the Standardized Precipitation - Evapotranspiration Index (SPEI). In order to characterize meteorological drought, it has been recommended to use the standardized precipitation index (SPI) developed by McKee et al. (1993) as a universal meteorological drought index because of its many advantages (WMO, 2006; WMO, 2012; Hayes et al., 2011). It is a simple and powerful index, only based on rainfall data; it enables the extraction of both the dry periods and wet periods. The SPI compares precipitation over different time scales from 1 to 24 months and across different regions (Guttman, 1994; Edwards and McKee, 1997).
Several drought studies used the SPI (eg. Wu et al., 2001; Keyantash and Dracup, 2002; Morid et al., 2006; Paulo and Pereira, 2006; Wu et al., 2007; Yildiz, 2009; Du et al., 2012; Jayanthi et al., 2013; Deo and Shahin, 2015; Ionita et al., 2016; Rimkus et al., 2017; Habibi et al., 2018).

Our objective in this study was to perform an assessment of the meteorological drought phenomenon, in the specified study area, over an annual time scale over 40 years, using the standardized precipitation index. This study is organized as follows:

I) Identification of ruptures (years of change) in the rainfall regime using statistical tests; II) Calculation of the annual SPI to determine the frequency and severity of the drought; III) Mapping the spatial evolution of drought on the basis of SPI classifications.

\section{MATERIAL AND METHODS}

\section{Study area and data}

The Upper and Middle Cheliff region is part of Cheliff, the largest basin in the north of Algeria. The study area is located at the longitude between $0^{\circ} 54^{\prime}$ and $3^{\circ} 5^{\prime}$ east, and the latitude between $35^{\circ} 35^{\prime}$ and $36^{\circ} 26^{\prime}$ north. It is subdivided into eleven sub-basins with a total area of $10930 \mathrm{~km}^{2}$ (see: Fig. 1). The study area is characterized by a semi-arid climate with relatively cold, rainy winters and hot, dry summers.

In this study 11 rainfall stations were selected according to the length of available rainfall records and their geographical positions in order to cover the whole region more efficiently. Each station represents a sub-basin. The annual rainfall was chosen, covering a period of 40 years (1970-2009). The statistical characteristics of rainfall stations are given in Table 1.

Average annual precipitation varies between 524 and $339 \mathrm{~mm} /$ year. In the Derrag, Zoubiria and Arib Ebda stations, the average precipitation is greater than $500 \mathrm{~mm}$. The coefficient of variation fluctuates between 24\% (Derrag) and 33\% (Souk El Had). Annual rainfall is low in the plains (e.g. El Ababsa, El Touaibia, El Abadia, Chlef DDA) compared to mountainous areas as well as areas south of the mountains (e.g. Derrag, Zoubiria, Fodda BGE).

The terrain and the distance to the sea are two important factors affecting the variability of precipitation. 

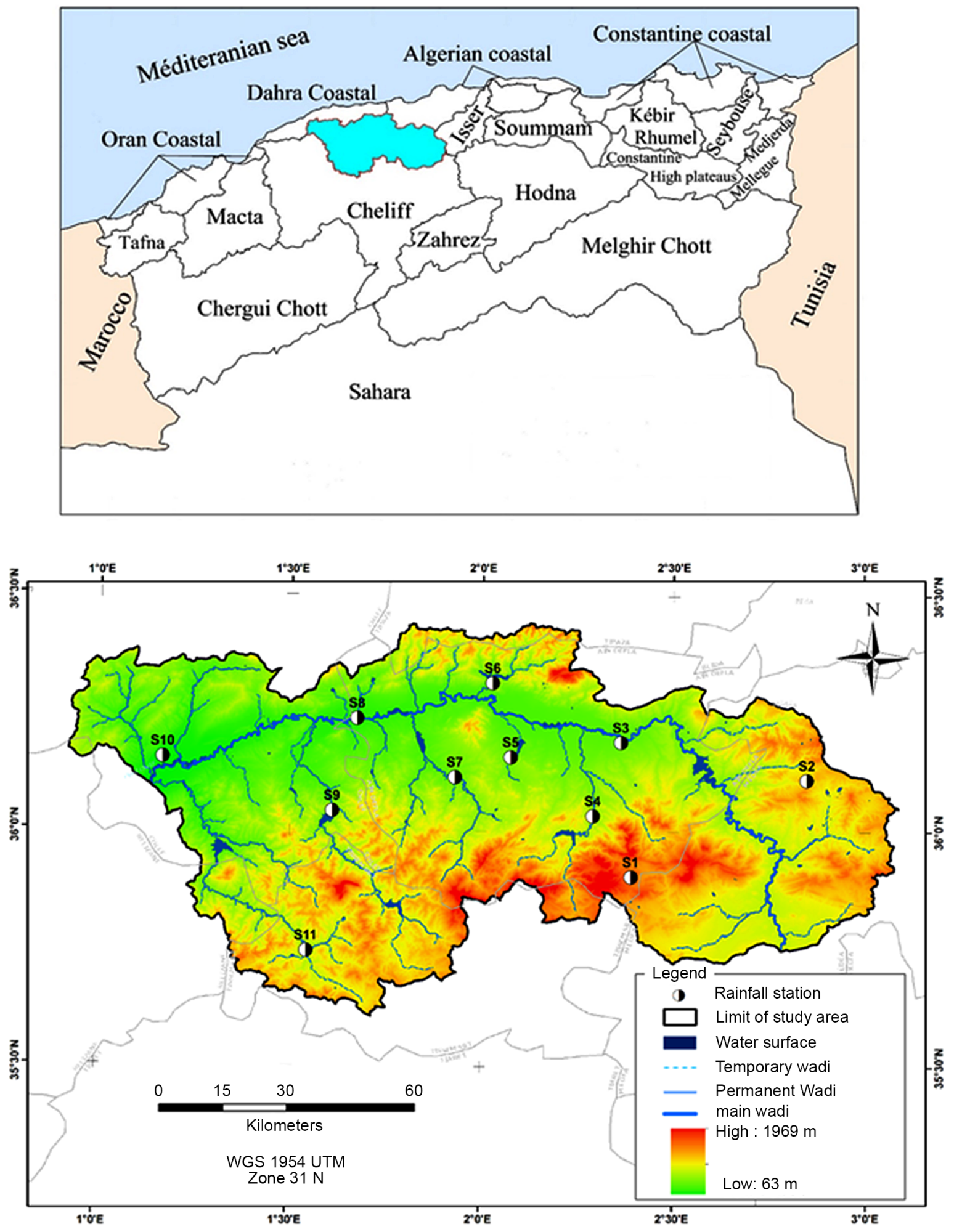

Fig. 1. Location of the study area and position of rainfall stations (Author: M. Achite) 
Fellag, M., Achite, M., Wałęga, A. (2021). Spatial-temporal characterization of meteorological drought using the Standardized Precipitation Index. Case study... Acta Sci. Pol., Formatio Circumiectus, 20 (1), 19-31. DOI: http://dx.doi.org/10.15576/ASP.FC/2021.20.1.19

Table 1. Descriptive statistics of rainfall stations in the study area

\begin{tabular}{|c|c|c|c|c|c|c|}
\hline $\begin{array}{c}\mathrm{N}^{\circ} \\
\text { station }\end{array}$ & Name & $X$ & Y & $\begin{array}{c}\text { Elevations of } \\
\text { station } Z \\
{[\mathrm{~m}]}\end{array}$ & $\begin{array}{c}\text { Average annual } \\
\text { rainfall } \\
{[\mathrm{mm}]}\end{array}$ & $\begin{array}{c}\text { Coefficient of } \\
\text { variability CV } \\
{[\%]}\end{array}$ \\
\hline $\mathrm{S} 1$ & Derrag & $02^{\circ} 23^{\prime} 23^{\prime \prime}$ & $35^{\circ} 54^{\prime} 26^{\prime \prime}$ & 1150 & 524 & 24 \\
\hline $\mathrm{S} 2$ & Zoubiria & $02^{\circ} 50^{\prime} 54^{\prime \prime}$ & $36^{\circ} 06^{\prime} 45^{\prime \prime}$ & 932 & 528 & 26 \\
\hline $\mathrm{S} 3$ & Domaine ferroukhi & $02^{\circ} 21^{\prime} 45^{\prime \prime}$ & $36^{\circ} 11^{\prime} 34^{\prime \prime}$ & 313 & 430 & 29 \\
\hline S4 & Sidi Mokrefi & $02^{\circ} 17^{\prime} 24^{\prime \prime}$ & $36^{\circ} 02^{\prime} 12^{\prime \prime}$ & 425 & 400 & 26 \\
\hline S5 & El Ababsa & $02^{\circ} 04^{\prime} 31^{\prime \prime}$ & $36^{\circ} 09^{\prime} 37^{\prime \prime}$ & 320 & 365 & 24 \\
\hline S6 & AribEbda & $02^{\circ} 01 ’ 34^{\prime \prime}$ & $36^{\circ} 19^{\prime} 04^{\prime \prime}$ & 280 & 501 & 25 \\
\hline S7 & El Touaibia & $01^{\circ} 55^{\prime} 48^{\prime \prime}$ & $36^{\circ} 07^{\prime} 01^{\prime \prime}$ & 350 & 306 & 30 \\
\hline S8 & El Abadia & $01^{\circ} 40^{\prime} 22^{\prime \prime}$ & $36^{\circ} 14^{\prime} 27^{\prime \prime}$ & 162 & 359 & 27 \\
\hline S9 & Fodda BGE & $01^{\circ} 36^{\prime} 37^{\prime \prime}$ & $36^{\circ} 02^{\prime} 41^{\prime \prime}$ & 432 & 416 & 30 \\
\hline $\mathrm{S} 10$ & Chlef DDA & $01^{\circ} 20^{\prime} 56^{\prime \prime}$ & $36^{\circ} 10^{\prime} 35^{\prime \prime}$ & 110 & 346 & 27 \\
\hline S11 & Souk El Had & $01^{\circ} 32^{\prime} 47^{\prime \prime}$ & $35^{\circ} 44^{\prime} 50^{\prime \prime}$ & 550 & 339 & 33 \\
\hline
\end{tabular}

\section{Statistical approaches for detecting discontinuities in precipitation series}

In order to detect discontinuities in rainfall data during the period 1970-2009, four statistical tests were applied to identify the break point [year of change] in the rainfall regime. According to Lubès et al. (1994), a break can be defined by a change in the probability law of the random variables whose successive realizations define the time series studied; this change point modifies the rainfall and hydrological regimes.

The time series breaks were detected using the following tests: test of Buishand (Buishand, 1982; 1984), test of Pettitt (Pettitt, 1979), test of Lee and Heghinian (Lee and Heghinian, 1977), and Hubert Segmentation (Hubert et al., 1989). These tests are integrated in the Khronostat software set up by the Research Institute for Development (IRD) and the University of Montpellier (Boyer, 1998).

\section{The standardized precipitation index SPI}

As mentioned earlier, in this paper, the Standardized Precipitation Index (SPI) has been applied to assess drought, as it allows comparisons over time and space, and can detect drought at different time scales (Edwards and McKee, 1997; Lloyd-Hughes and Saunders,
2002; Bonaccorso et al., 2003; Sonmez et al., 2005, Vicente-Serrano, 2006; Wu et al, 2007).

The calculation of the SPI requires the adjustment of the collected rainfall series to a probability curve (McKee et al., 1993). Since the distribution of precipitation is generally positively asymmetric, a transformation is applied to the data in order to render their distribution normal or Gaussian (Sharma, 1997). Most often, the choice of the transformation concerns the Gamma's law probability. Although adjustment to this law can be done by analytical methods, a statistical method based on shape and scale parameters according to Edwards and McKee (1997) is used. The gamma distribution is defined by its probability density represented by:

$$
g(x)=\frac{1}{\beta^{\alpha} \Gamma(\alpha)} x^{\alpha-1} e^{\alpha / \beta} \text { for } x>0
$$

Where $\alpha$ and $\beta$ are the shape and scale parameters, respectively. $\Gamma(\alpha)$ represents the mathematical gamma function and $\mathrm{x}$ is the amount of precipitation.

Using the resulting parameters to find the accumulated probability of an observed precipitation episode, the cumulative probability (distribution function) becomes: 


$$
G(x)=\int_{0}^{x} g(x) d x=\frac{1}{\hat{\beta} \hat{\alpha} \Gamma(\hat{\alpha})} \int_{0}^{x} x^{\hat{\alpha}-1} e^{-x \hat{\beta}} d x
$$

Allowing that $t=x / \hat{\beta}$, this equation becomes the incomplete gamma function:

$$
G(x)=\frac{1}{\Gamma(\hat{\alpha})} \int_{0}^{x} t^{\hat{\alpha}-1} e^{-1} d t
$$

Since the gamma function is not defined for $x=0$ and a precipitation distribution can contain zeros, the cumulative probability becomes:

$$
H(x)=q+(1-q) G(x)
$$

$H[\mathrm{x}]$ is the cumulative probability when $X=0$ and $q$ is the frequency of zero precipitation. In this last calculation, the cumulative probability is only the variable $Z$; a standard normal distribution characterized by a mean value of zero and a variance of one. After this transformation, the calculated values give the value of the SPI (Nuñez-Lopez, 2006). The wet and dry periods can be represented in the same way; thus, wet periods can also be displayed using the SPI.

The SPI in this study was calculated using annual precipitation data (hydrological year), which implies that we used a specific case of SPI-12. We have listed the SPI classes of the severity of drought in Table 2.

Table 2. Classification of drought on the basis of SPI values (McKee et al., 1993)

\begin{tabular}{|c|c|}
\hline SPI Values & Drought Category \\
\hline 2.00 or more & Extremely wet \\
\hline 1.50 to 1.99 & Very wet \\
\hline 1.00 to 1.49 & Moderately wet \\
\hline-0.99 to 0.99 & Moderately drought \\
\hline-1.00 to -1.49 & Severely drought \\
\hline-1.50 to -1.99 & Extremely drought \\
\hline-2.0 or less & \\
\hline
\end{tabular}

\section{RESULTS AND DISCUSSION}

The chronological evolution of the rainfall regime and the trend observed between 1970 and 2009 are illustrated in Figure 2. The analysis of the annual precipitation trend was negative in all rainfall stations. The annual rainfall at Souk Elhad (S11) revealed a notable change in the year 1974. Precipitation decreased by more than $370 \mathrm{~mm}$, down to $150 \mathrm{~mm}$. El Touaibia (S7) had a deficit period from 1980 to 1993 (reaching $200 \mathrm{~mm}$ ). A strong fluctuation of precipitation had been recorded in all stations, from one year to another. These conclusions were confirmed by the statistical tests of break in rainfall data.

The break years are identified by the four statistical tests, and the results are summarized in Table 3 showing that for almost all the stations, a rupture (changes in the annual rainfall) appeared between the end of the 1970s and the beginning of the 1980s, whereas the years $1979 / 80$ and 1982 were the years of change and the beginning of a deficit of rainfall. Domaine Ferroukhi Station recorded a break outside these dates (1973).

Only Derrag station did not record any break. This absence of rupture does not mean the absence of a decrease in rainfall. There was a variation of the rainfall regime, but it remained insignificant (Lubès et al., 1994). The calculation of the reduction rate for the 11 time series shows that there is a downward trend in rainfall totals, and this reduction rate varies between $19.7 \%$ and $32.6 \%$ (negative values).

The SPI time series were calculated for all rainfall stations in the study area, at an annual time scale, for the period 1970-2009. Figure 3 shows that the 1970-1979 decade had no drought except in the two stations Arib Ebda (S6) in 1970 and the station Souk el Had (S11) in 1974. This wet decade (1970-79) was followed by alternating dry and wet years.

Drought is often repeated, and this is due to the deficiency of rainfall. In terms of frequency, the evolution of SPI revealed a dominance of normal years $(67 \%)$ compared to dry years $(17 \%)$ and wet years $(16 \%)$. These two classes show a certain alternation in the studied area.

The drought persisted during the years 1992-1993, 1999, 2001 and 2004. These years marked critical drought with values lower than -2 . There was also an 

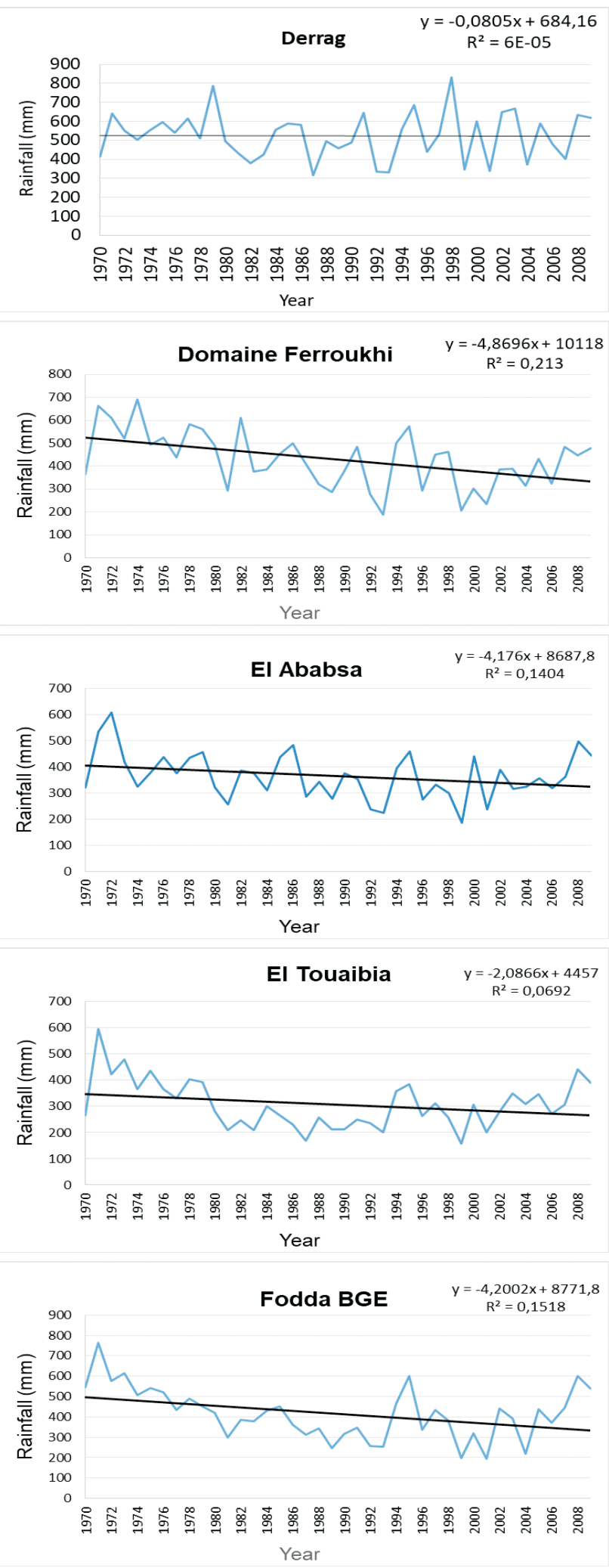
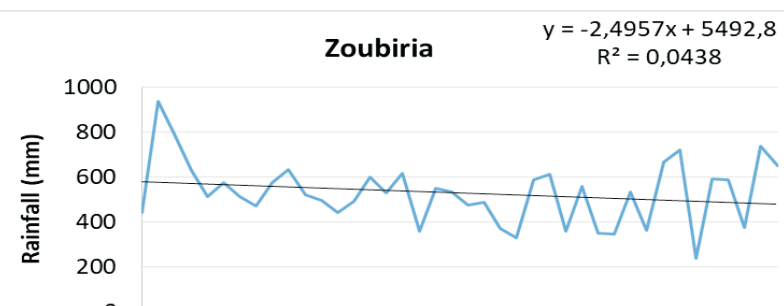

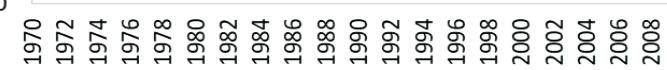
Year
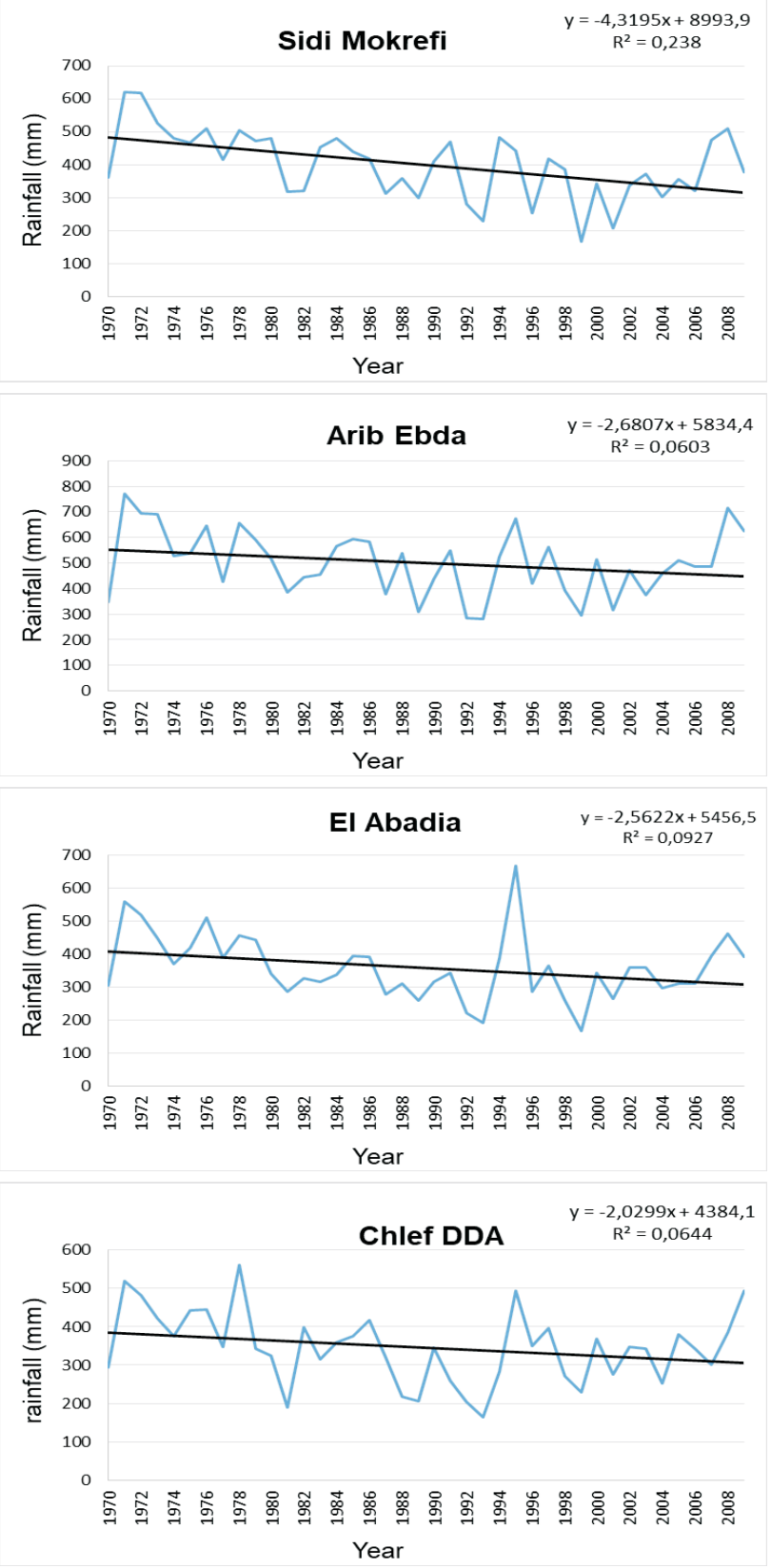

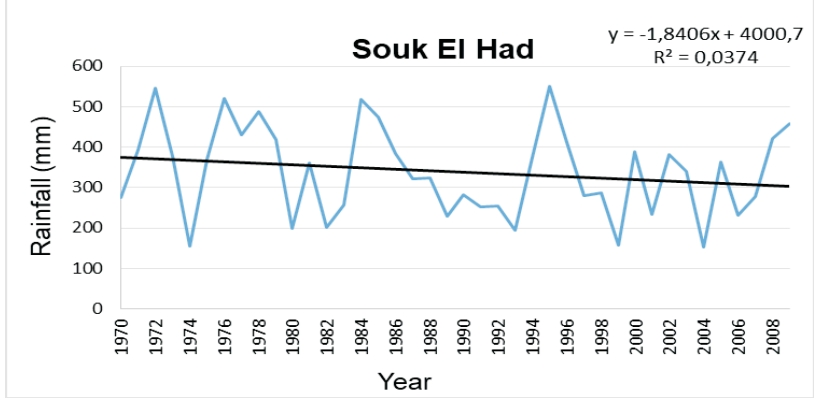

Fig. 2. Time series of annual rainfall and trend for studied stations 
Fellag, M., Achite, M., Wałęga, A. (2021). Spatial-temporal characterization of meteorological drought using the Standardized Precipitation Index. Case study... Acta Sci. Pol., Formatio Circumiectus, 20 (1), 19-31. DOI: http://dx.doi.org/10.15576/ASP.FC/2021.20.1.19

Table 3. Years of rainfall ruptures over the period 1970-2009

\begin{tabular}{cccccccc}
\hline Station & $\begin{array}{c}\text { Buishand } \\
\text { test }\end{array}$ & $\begin{array}{c}\text { Pettitt } \\
\text { test }\end{array}$ & $\begin{array}{c}\text { Lee and } \\
\text { Heghinian test }\end{array}$ & $\begin{array}{c}\text { Hubert } \\
\text { segmentation }\end{array}$ & $\begin{array}{c}\text { Average before } \\
\text { break }\end{array}$ & $\begin{array}{c}\text { Average } \\
\text { after break }\end{array}$ & $\begin{array}{c}\text { Rate } \\
\text { reduction [\%] }\end{array}$ \\
\hline S1 & - & - & - & - & & & \\
\hline S2 & - & - & 1973 & 1973 & 699,3 & 508,6 & $-27,3$ \\
\hline S3 & + & 1982 & 1980 & 1980 & 540,7 & 387,9 & $-28,3$ \\
\hline S4 & + & 1980 & 1980 & 1980 & 496,4 & 363,8 & $-26,7$ \\
\hline S5 & + & - & 1979 & 1979 & 429,13 & 343,4 & $-20,0$ \\
\hline S6 & - & - & 1979 & 1979 & 589,4 & 471,8 & $-20,0$ \\
\hline S7 & + & 1979 & 1979 & 1979 & 404,7 & 272,7 & $-32,6$ \\
\hline S8 & + & 1979 & 1979 & 1979 & 441,9 & 331,3 & $-25,0$ \\
\hline S9 & + & 1979 & 1979 & 1979 & 544,3 & 372,7 & $-31,5$ \\
\hline S10 & + & 1979 & 1979 & 1979 & 431,3 & 320,7 & $-25,6$ \\
\hline S11 & - & - & 1979 & 1979 & 397,5 & 319,2 & $-19,7$ \\
\hline
\end{tabular}

absence of drought recorded between 2005 and 2009. In order to better visualize the results obtained by the standardized precipitation index (SPI) and to compare the sub-basins with each other, a mapping has been established. In Figure 4, we distinguished the succession of the particular dry and wet episodes, and areas affected by drought. The years 1989, 1992, 1993, 1999, 2001 and 2004 were marked by a severe drought. The wet years are also listed (1971, 1972, 1995, and 2009). During the years 1993 and 1999, the whole area was severely affected by drought.

Rainfall analysis during the studied period (1970 2009) showed decreasing trends in rainfall data over the study area. The temporal evolution of the standardized precipitation index (SPI) has revealed the existence of dry episodes followed by wet intervals. Extreme values of the Standardized Precipitation Index have been recorded in the studied stations, which are characterized by extremely severe droughts (see: Fig. 4). These results are consistent with several studies on rainfall and drought in northern Algeria (Demmak, 1982; Khaldi, 2005; Meddi and Meddi, 2009; Meddi and Toumi, 2013; Khoualdia, 2015).

Statistical methods have confirmed the transition of the rainfall regime between the 1970s and the 1980 s, indicating that drought had appeared in the ma- jority of Mediterranean countries since the early 1980 s (IPCC, 2007, IPCC 2008, Kadi 1995, Blöchliger and Neidhöfer 1998) and in Algeria (Djellouli and Daget, 1993; Talia and Meddi, 2004; Hirche et al., 2007; Zeineddine, 2011; Zeineddine et al., 2013).

The rainfall deficit during the 1980s and 1990s was estimated at $30 \%$ in eastern Algeria, and also $30 \%$ for the central and western regions (Kettab, 2002). Severe meteorological drought, recorded over several years, can implicate important problems with water quantity also in the context of climate change projections. As demonstrated by Hadour et al. (2020) in the case of the Haciabia, Sidi Djillali, Ammi Moussa, Ouled Ben AEK and Chouly basins in Algieria, decrease of rainfall and increase of ETP can influence downward trend of flow for the two scenarios RCPs 8.5 and 4.5. Therefore it is very important to prevent drought and water scarcity with a rational use of water resources.

According to the estimates by the Intergovernmental Panel on Climate Change (IPCC) for the period 1990-2020, we should expect an increase in the average temperature by 0.8 to $1.1^{\circ} \mathrm{C}$, and a reduction of rainfall by $10 \%$. Decreased precipitation and increased evaporation will affect dams and groundwater (Sahnoune et al., 2013). 


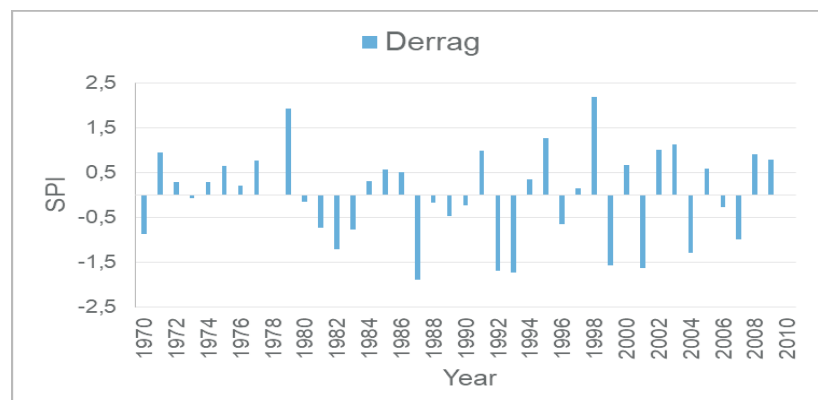

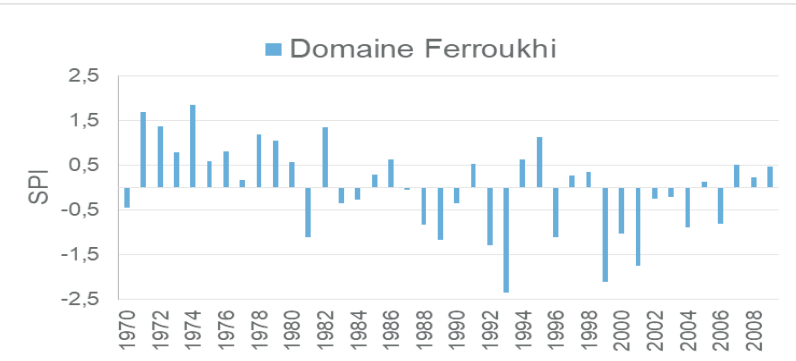
Year

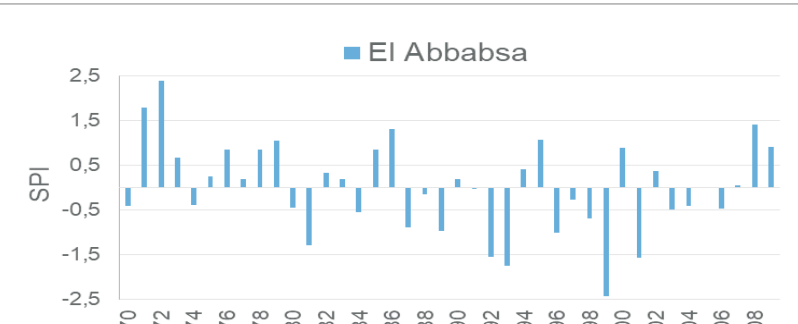

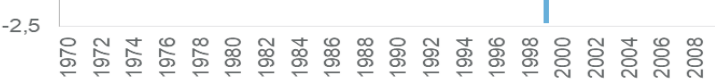
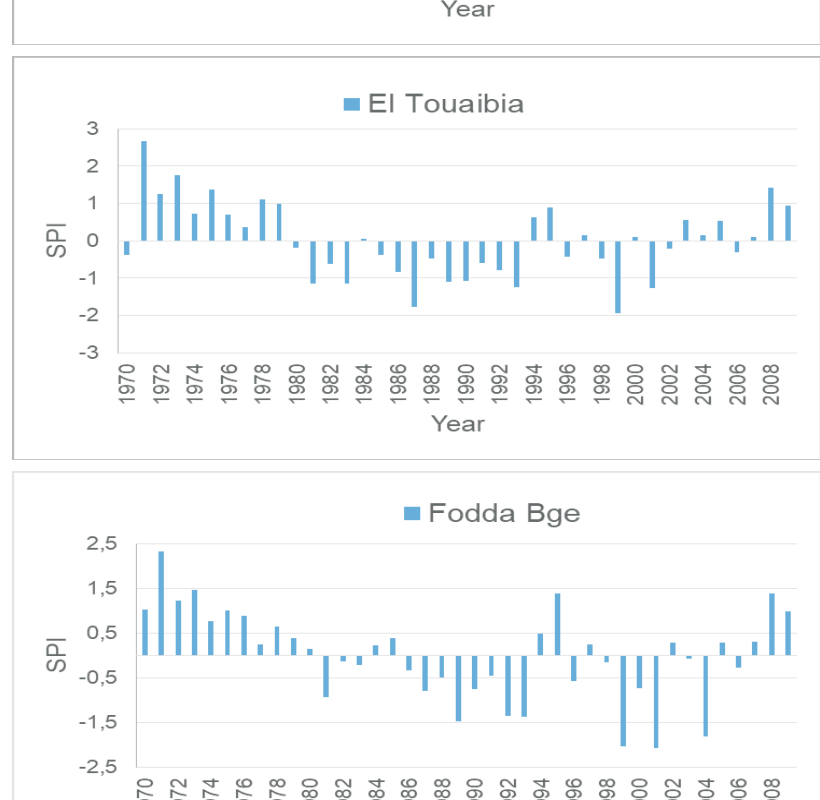

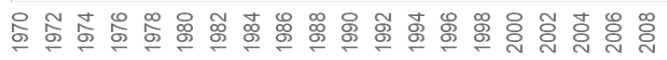

$$
\text { Year }
$$

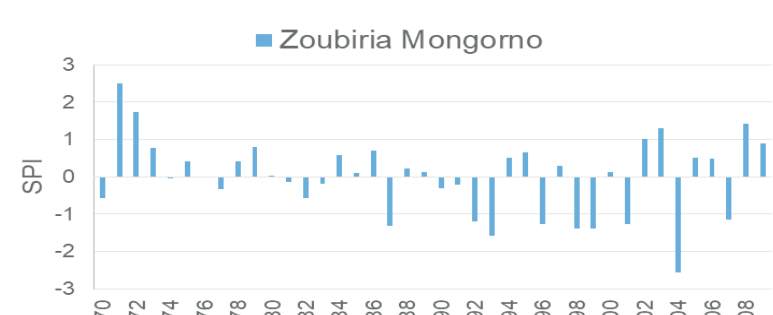

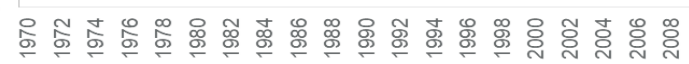
Year

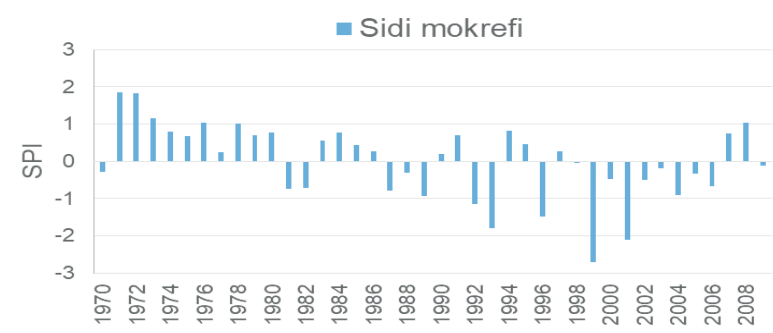
year

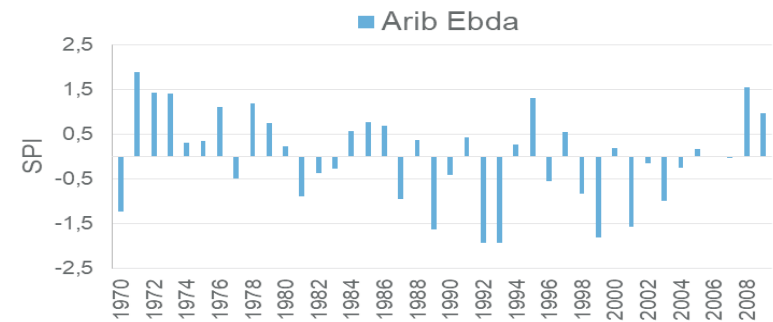

Year

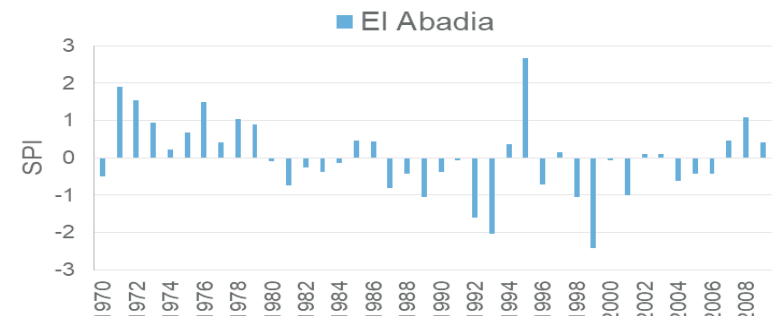
Year

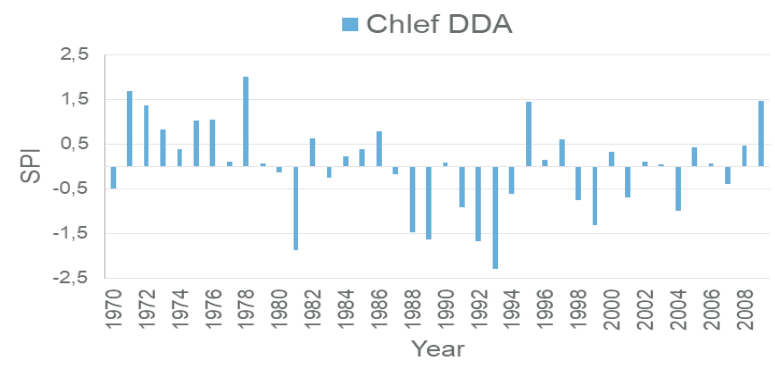

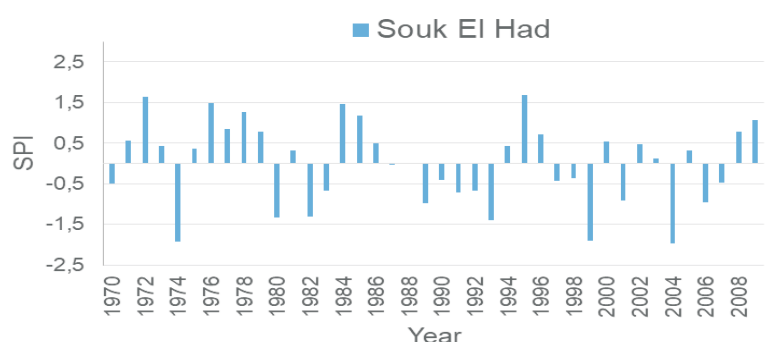

Fig. 3. 1-year SPI for the rain stations in study area 


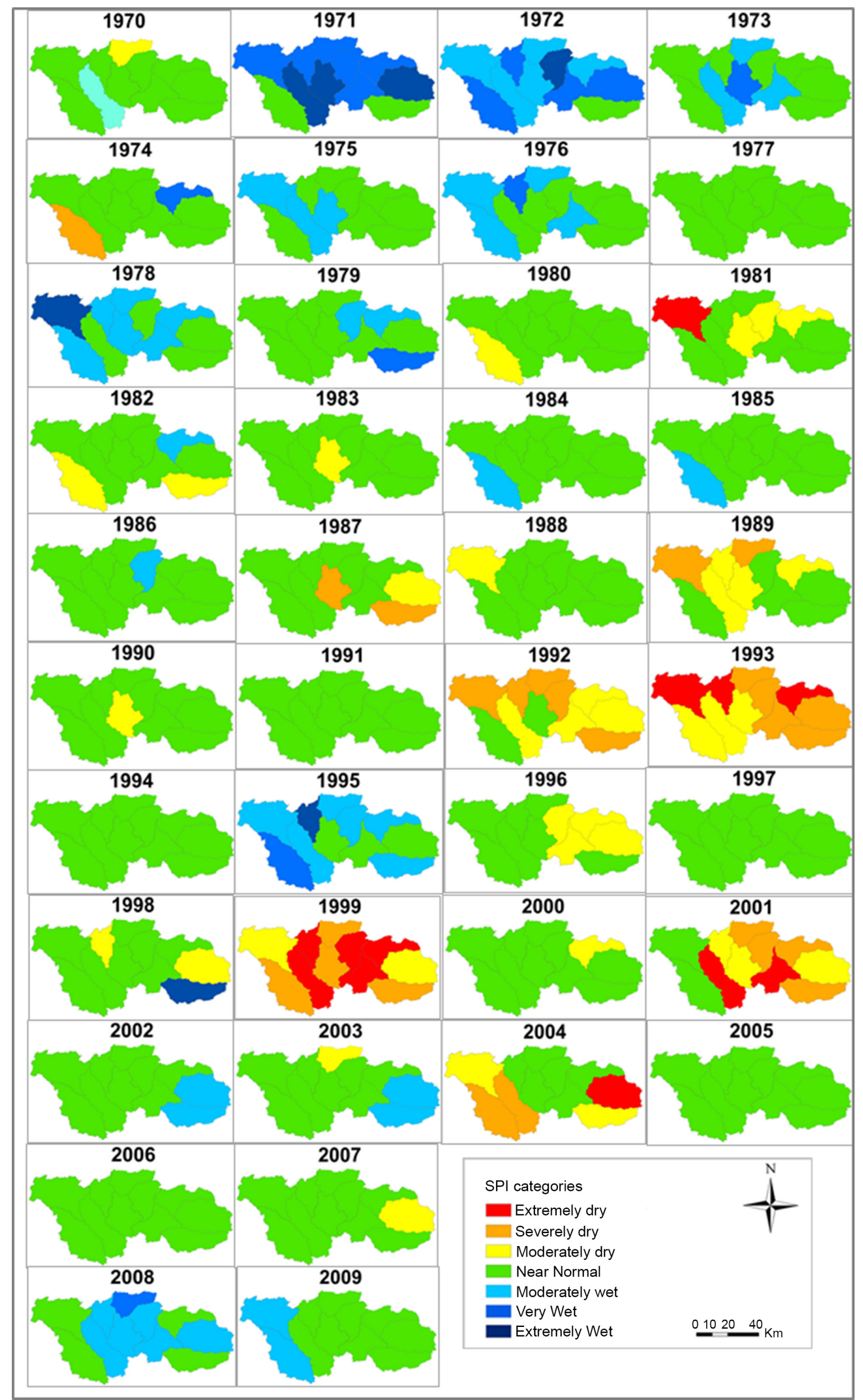

Fig. 4. Spatial variability of drought based on SPI value (Author: M. Achite) 

tation Index. Case study... Acta Sci. Pol., Formatio Circumiectus, 20 (1), 19-31. DOI: http://dx.doi.org/10.15576/ASP.FC/2021.20.1.19

\section{CONCLUSION}

In order to characterize the spatial and temporal variability of meteorological drought in the Upper and Middle Cheliff region at an annual time scale, the severity of drought has been calculated using the standardized precipitation index based on precipitation data (1970 to 2009). Rainfall variability analysis showed that precipitation tends to decrease from year to year, and that the rupture of the precipitation series appeared between the late 1970s and the early 1980s.

The study revealed that the onset of drought was detected in $1979 / 80$, and that the drought peaked in 1989, 1992, 1993, 1999, 2001 and 2004. The spatial distribution of drought indicated that during 1993 and 1999; the entire surface of the studied area was affected by drought. Drought is a frequent phenomenon that has always affected humans and their environment. The application of SPI is useful for developing an appropriate water management strategy and can help decision-makers around the world to take drought risks into account.

\section{REFERENCES}

Achite M., Touaibia B. (2007). Sécheresse et gestion des ressources en eau dans le bassin versant de la Mina, In : XIIIème Congrès Mondial de l'Eau, Gestion de la demande en eau en Méditerranée, progrès et politiques.

Beltrando G., Cambrelin P. (1995). Les sécheresses en Ethiopie et dans l'Est de l'Afrique. Sécheresse 1, 87-94.

Blöchliger H., Neidhöfer F. (1998). Impacts des précipitations extrêmes, Rapport de l'orange consultatif enmatière de recherche sur le climat et les changements climatiques, 40.

Blumenstock G.J. (1942). Drought in the United States analyzed by means of the theory of probability. USDA Technical Bulletin, 819, 1-64.

Bonaccorso B., Bordi I., Cancelliere A., Rossi G.,Sutera A. (2003). Spatial Variability of Drought: An Analysis of the SPI in Sicily. Water Resources Management 17 (4), 273-296.

Boyer J.F. (1998). Khronostat statistical time series analyses software. Montpellier : UMR 5569 Hydrosciences. IRD- Maison des sciences de l'eau. http://www.hydrosciences.org/spip.php/article239
Buishand T.A. (1982). Some methods for testing the homogeneity of rainfall records. Journal of Hydrology 58(1-2), 11-27.

Buishand, T. A. (1984). Test for detecting a shift in the mean of hydrological time series. Journal of Hydrology 73[1-2], 51-69.

Demmak, A. (1982). Contribution à l'étude de l'érosion et des transports solides en Algérie septentrionale Thèse, Docteur-Ingénieur. Université de Paris, France.

Deo R.C., Şahin M. (2015). Application of the Artificial Neural Network model for prediction of monthly Standardized Precipitation and Evapotranspiration Index using hydrometeorological parameters and climate indices in eastern Australia. Atmospheric Research,54-81.

Djellouli Y., Daget P H., 1993. Conséquences de la sécheresse des deux dernières décennies sur les écosystèmes naturels algériens, Publications Association Internationale de Climatologie 6, 105-114.

Dracup J.A., Lee K.S., Edwin G., Paulson J.R. (1980). On the definition of droughts. Water Resources Research 16(2), 297-302.

Du J., Fang J., Xu W., Shi P. (2012). Analysis of dry/wet conditions using the standardized precipitation index and its potential usefulness for drought/flood monitoring in Hunan Province, China. Stochastic Environmental Research and Risk Assessment 27, 377-387.

Edossa D.C., Babel M.S., Gupta A.D. (2010). Drought analysis in the Awash river basin, Ethiopia. Water Resources Management 24(7), $1440-1460$.

Edwards D.C., Mckee T.B. (1997). Characteristics of the 20th century drought in the United States at multiple time scales. Atmospheric Science Paper 634, 1-30.

Farmer G., Wigley T M L. (1985). Climatic Trends for Tropical Africa Research Report. University of East Anglia, Norwich, UK.136

Guttman N.B. (1994). On the sensitivity of sample L moments to sample size. Journal of Climatology 7, 1026-1029.

Habibi ,B, Meddi, M, Torfs, Paul, J.J.F, Remaoun M, Van Lanen, Henny A.J. (2018). Characterisation and prediction of meteorological drought using stochastic models in the semi-arid Chéliff-Zahrez basin (Algeria). Journal of Hydrology: Regional Studies 16, 15-31. doi.org/10.1016/j.ejrh.2018.02.005

Hamlaoui-Moulai L., Mesbah M., Souag-Gamane D., Medjerab A. (2013). Detecting hydro-climatic change using spatiotemporal analysis of rainfall time series in Western Algeria. Natural Hazards 65, 1293-1311.

Hayes MJ., Svoboda MD., Wall N., Widhalm M. (2011). The Lincoln declaration on drought indices: universal 
meteorological drought index recommended. Bulletin of American Meteorological Society, 92, 485-488.

Hadour A., Mahé G, Meddi M. (2020). Watershed based hydrological evolution under climate change effect: An example from North Western Algeria. Journal of Hydrology: Regional Studies, 28, 100671,

Hirche A., Boughani A., Salamani M. (2007). Évolution de la pluviosité dans quelques stations arides algériennes. Sécheresse 18(4), 314-320.

Hubert P., Carbonnel J. P., Chaouche A. (1989). Segmentation des séries hydrométéorologiques. Application à des séries de précipitations et de débits de l'Afrique de l'Ouest. Journal of Hydrology 110, 349-367.

Ionita M., Scholz P., Chelcea S., (2016). Assessment of droughts in Romania using the Standardized Precipitation Index , Natural Hazards 83(3), 1483-1498. DOI: 10.1007/s11069-015-2141-8

IPCC (Intergovernmental Panel on Climate Change) (2007) Rapport 2007 sur l'évolution du climat.Genève.

IPCC. (2008). Changements climatiques et impacts dans les Alpes. Résultats du WP5 du projet Clim Ch Alp. Rapport Technique $\mathrm{N}^{\circ} 1$ de l'ONERC, France.

Jayanthi H., Husak G.J., Magadzire T, Chavula A, Verdin, J.P. (2013). Modeling rain-fed maize vulnerability to droughts using the standardized precipitation index from satellite estimated rainfall Southern Malawi case study. International Journal of Disaster Risk Reduction. doi. org/10.1016/j.ijdrr.2013.02.001

Kadi, D. (1995). Contribution à l'étude de la sécheresse sur le littoral algérien par le biais de traitement des données pluviométriques et la simulation, Thèse de Magister. Ecole nationale polytechnique d 'Alger.

Kettab A., Ait Mouhoub D., Ouarda T., Bobbee B. (2002). Contribution à l'étude du phénomène de la sécheresse sur les régions littorales de l'Algérie » Laboratoire de recherche en Sciences de l'eau - LRS - EAU/ENP Ecole Nationale Polytechnique (E.N.P) - Alger; Colloque international sur l'eau, Chlef, Algérie.

Keyantash J., Dracup JA. (2002). The quantification of drought: an evaluation of drought indices. Bulletin of American Meteorological Society 83(8),1167-1180 .

Khaldi, A. (2005). Impacts de la sécheresse sur le régime des écoulements souterrains dans les massifs calcaires de 1 'Ouest Algérien Monts de Tlemcen - Saida, Thèse de Doctorat d'état. Université d 'Oran, Algérie.

Khoualdia W. (2015). Contribution à l'étude de la variabilité climatique et son impact sur les ressources hydriques. Cas d'oued Medjerda Nord-Est Algérie. Thèse de Doctorat d'état. Université d 'Annaba, Algérie.
Lee AFS., Heghinian MS. (1977). A Shift of the Mean Level in a Sequence of Independent Normal Random VariablesA bayesian approach. Technometrics 19(4), 503-506.

Lloyd- Hughes B., Saunders MA. (2002). A drought climatology for Europe. International Journal of Climatology 22(13), 1571- 1592.

Lubès H., Masson M., Servat E., Paturel JE., Kouame B., Boyer JF. (1994). Caractérisation de fluctuations dans une série chronologique par applications de tests statistique. Rapport No 3. Programme ICCARE.

Matari A., Douguedroit A. (1995). Chronologie des précipitations et des sécheresses dans l'ouest Algérien. In: Les stratégies pour le contrôle des sécheresses, Proc. 9eConférence régionale afro-asiatique des Irrigations et du Drainage. Alger, June 1995.

McKee TB., Doesken NJ., Kleist J. (1993). The relationship of drought frequency and duration to time scales. In: Proceedings of the 8th Conference on Applied Climatology. Anaheim California, USA. 179-184.

McQuigg J. (1954). A simple index of drought conditions. Weatherwise 7, 64-67.

Meddi, M., Hubert, P. (2003). Impact de la modification du régime pluviométrique sur les ressources en eau du Nord -Ouest de 1 'Algérie. In: Servat Najem, E., Leduc, W., Shakeel, E.A. [Eds.], Hydrology of the Mediterranean and Semiarid Regions, pp. 229-235 [IAHS Publ. no. 278].

Meddi H., Meddi M.( 2009). Study of the persistence of drought at the level of seven Algerian plains by use of chain of MARKOV [1930-2003]. Courrier du Savoir 9, 39-48.

Meddi, M., Toumi, S. (2013). Study of the interannual rainfall variability in northern Algeria. Le Journal de l'Eau et de l'Environnement 12(23), 40-59.

Morid S., Smakhtin V., Moghaddasi M. (2006). Comparison of seven meteorological indices for drought monitoring in Iran. International Journal of Climatology 26 (7), 971-985.

Munger, T.T. (1916). Graphic method of representing and comparing drought intensities. Monthly Weather Revew 44 (11), 642-643

Nunez Lopez D., Munoz Robles CA., Gadsden H., Reyes Gomez VM. (2006). Caractérisation à diverses échelles de temps, des séquences de sécheresse dans l'État de Chihuahua (Mexique) Sécheresse 17, 467-474.

Palmer WC. (1965). Meteorological droughts. U.S. Department of Commerce Weather Bureau Research Paper 45, Washington, DC.

Paturel JE., Servat E., Kouamé B., Lubès H., Ouedraogo M, Masson JM. (1997). Climatic variability in humid Africa along the Gulf of guinea. Part II: an integrated regional approach. Journal of Hydrology 191(1-4), 16-36. 

tation Index. Case study... Acta Sci. Pol., Formatio Circumiectus, 20 (1), 19-31. DOI: http://dx.doi.org/10.15576/ASP.FC/2021.20.1.19

Paulo AA., Pereira LS. (2006). Drought concepts and characterization: Comparing drought indices applied at local and regional scales. Water International 31(1), $37-49$.

Pettitt AN. (1979). A non-parametric approach to the changepoint problem. Applied Statistics 28(2), 126-135.

Rimkus E., Edvinas S., Justinas k., Viktorijam., Donatas V. (2017). Drought identification in the eastern Baltic region using NDVI. Earth System Dynamics. 8, 627-637, https://doi.org/10.5194/esd-8-627-2017.

Sahnoune F., Belhamel M., Zelmat M., Kerbachi R. (2013). Climate Change in Algeria: Vulnerability and Strategy of Mitigation and Adaptation. Energy Procedia 36, 1286-1294

Seltzer, P. (1946). Le climat de l'Algérie. Travaux de l'Institut de météorologie et de physique du globe de l'Algérie, hors sér. Université d'Alger (La Typo-litho \& J.Carbonel Alger).

Servat E., Paturel JE., Lubès H., Kouamé B., Masson JM., Travaglio M,. Marieu B. (1999). De différents aspects de la variabilité de la pluviométrie en Afrique de l'Ouest et Centrale non sahélienne. Revue des Sciences de l'Eau 12(2), 363-387. DOI : 10.7202/705356

Sharma TC. (1997). Estimation of drought severity on independent and dependant hydrologic series. Water Resources Management 11, 35-49.

Sonmez FK., Komuscu AU., Erkan A., Turgu E. (2005). An analysis of spatial and temporal dimension of drought vulnerability in Turkey using the standardized precipitation index. Natural Hazards 35(2), 243-264.

Vicente-Serrano SM. (2006). Spatial and temporal analysis of droughts in the Iberian Peninsula [1910-2000]. Hydrologycal Sciences Journal 51(1), 83-97.

Taibi S., Meddi M., Mahé G., Assani, A. (2017). Relationships between atmospheric circulation indices and rainfall in Northern Algeria and comparison of observed and RCM-generated rainfall. Theoretical and Applied Climatology 127 (1-2), 241-257.

Talia A., Meddi M. (2004). La pluvio-variabilité dans le Nord de l'Algérie. Actes du colloque «Terre et Eau» Annaba, 477-480.
Wilhite DA., Glantz MH. (1985). Understanding the drought phenomenon: the role of definitions. IWRA, Water International 10, 111-120.

WMO. (2006). Drought Monitoring and Early Warning: Concepts, Progress and Future Challenges, WMO-No. 1006. World Meteorological Organization, Geneva, Switzerland.

WMO (2012). Standardized precipitation index user guide. In: Svoboda, M., Hayes, M., Wood, M. [Eds.], World Meteorological Organization Report WMO-No. 1090, [Geneva, Switzerland].

Wu H., Hayes MJ., Welss A., Hu Q. (2001). An evaluation the standardized precipitation index, the china-z index and the statistical z-score. International Journal of Climatology 21(6), 745-758.

Wu, H., Svoboda, M., Hayes, M., Wilhite, D., Wen, F. (2007). Appropriate application of the Standardized Precipitation Index in arid locations and dry seasons. International Journal of Climatology 27(1), 65-79.

Yildiz O. (2009). Assessing temporal and spatial characteristics of droughts in the Hirfanli dam basin, Turkey. Scientific Research and Essay 44, 249-255.

Zeineddine N. (2011). Vers un retour des pluies sur la rive sud du bassin méditerranéen occidental: analyse et évaluation de la tendance pluviométrique sur plus d'un demi - siècle en Algérie. The Annals of Valahia University of Târgovişte, Geographical Series, 11.

Zeineddine N., Benoit L., et Imen T. (2013). Changements climatiques au Maghreb : vers des conditions plus humides et plus chaudes sur le littoral algérien ? Géographie Physique et Environnement 7, 307-323.

Zeroual A., Meddi M., Bensaad S. (2013). The impact of climate change on river flow in arid and semi-arid rivers in Algeria. In: Climate and Land-surface Changes in Hydrology, Proceedings of H01, IAHS-IAPSO-IASPEI Assembly, Gothenburg, Sweden, IAHS Publicaions 359, 105-110.

Zeroual, A., Assani, A.K., Meddi, M. (2017). Combined analysis of temperature and rainfall variability as they relate to climate indices in Northern Algeria over the 1972 -2013 period. Hydrology Research. 48, 584-595. 
CZASOPRZESTRZENNA CHARAKTERYSTYKA SUSZY METEOROLOGICZNEJ PRZY WYKORZYSTANIU STANDARYZOWANEGO WSKAŹNIKA OPADU (SPI). PRZYKŁAD BADAŃ W ALGIERII

\section{ABSTRAKT}

\section{Cel pracy}

Celem pracy była czasoprzestrzenna analiza występowania suszy meteorologicznej w górnym i środkowym Cheliff; półsuchym regionie północno-zachodniej Algierii. Suszę meteorologiczną analizowano w oparciu o standardowy wskaźnik opadów (SPI).

\section{Metody badań}

Do określenia wskaźnika SPI wykorzystano roczne sumy opadów z 11 stacji opadowych z lat 1970-2009. W celu zidentyfikowania możliwych zmian trendu opadów badanych szeregów wykorzystano testy statystyczne. Określono dotkliwość i czas trwania suszy na badanym obszarze.

\section{Najważniejsze wyniki i wnioski}

Analizy wykazały, że na przełomie lat 70. i 80. XX wieku stwierdzono występowanie zmian w reżimie opadów z na tendencję malejącą. Wskaźnik SPI wykazał występowanie lat suchych po 1979 i 1980 roku. Lata 1993, 1999 i 2001 charakteryzowały się wyjątkowo dotkliwą suszą (SPI <-2). Ponadto wykazano dominację lat normalnych (67\%), suchych (17\%) i mokrych (16\%) w okresie 40 lat. Susza występowała na całym obszarze w latach 1993 i 1999). Badany obszar charakteryzuje się nieregularnością i niejednorodnością suszy, ze względu na dużą zmienność opadów atmosferycznych.

Słowa kluczowe: dotkliwość suszy, zmienność opadów, wskaźnik standaryzowanego opadu, Algeria 